\title{
ISLAMOPHOBIA: A PROJECTION OF THE WEST'S 'DARK SIDE'
}

\author{
Arthur F. Buehler*
}

\begin{abstract}
Humankind is more interconnected now than ever before. Some celebrate this shared humanity while too many others appear fixated more on their own ethnic group, nationality, or religion. In the personal view of the author, 'islamophobia' is an ungrounded fear of something/someone that does not exist in reality and which involves a psychological projection to create 'the other' as enemy. The focus of this spirited article is on the development of 'islamophobia' out of an earlier 'syndrome' of religio-political antagonism. It is seen by the author as spreading via the mass media 'like a virus'. He argues that this phenomenon is a psychological defence mechanism involving the projection of what he refers to as 'the West's dark side' onto Islam and its followers. ${ }^{1}$
\end{abstract}

Human beings are members of a whole, created of one essence and soul. If one member is troubled by pain, others suffer severe strain. You who have no sympathy for human pain, deserve not the name human to retain.

Sa 'dī (d. 1292), Gulistān (Chapter 1, Story 10)

\section{Introduction: A Brief History of Islamophobia}

Western animosity toward Islam and Muslims is not just a post 9/11 phenomenon. There are ample historical precedents. In the past, Islam and its followers became a new religio-political enemy for the Christians after most of the Middle East and North Africa, which had been under Christian Byzantine control, had come under Muslim rule in the seventh and eighth centuries. The Battle of Poitiers in 732, where the Franks defeated the invading Arabs, was still considered in the twentieth century to be the most decisive battle in early medieval European history. ${ }^{2}$ It was after this battle that a certain 'Isidorus Pacensis', an otherwise unattested

* Arthur F. Buehler is Senior Lecturer at Victoria University in Wellington, New Zealand. 
eighth-century bishop of what is now Beja in Portugal, coined the term Europenses (Europeans) to describe the new identity of Christians who defeated Muslim armies in this battle. ${ }^{3}$ Islam as the 'religion of the sword' and 'the enemy other' appears to be deeply embedded both in Christendom's and the modern West's collective cultural unconscious.

Between the Battle of Poitiers and the Crusades (1095-1291), initiated by Pope Urban II, Western Europeans had little direct contact with Muslims, aside from the almost constant warfare between them in Spain and the Mediterranean. As a result, Muslims remained distant foes in the European consciousness for many centuries. The anti-Islamic Byzantine literature displays some first-hand knowledge of Islamic faith and practices, treating Islam as a religious heresy like paganism or Manichaeism and accusing Muhammad of being an Arian heretic. ${ }^{4}$ It is only from the late eleventh century (at the time of the First Crusade) that Byzantine knowledge of Islam gradually increases over the next four centuries.

The Crusades reinforced an image of Islam's wealth and luxuries of worldly life, which is in contrast to the relatively undeveloped societies of Christendom at this time. ${ }^{5}$ As invaders, the Crusaders only saw the 'glitter' of Muslim civilisation without recognising the pietist undercurrents that contributed to its distinctive strengths. Not only did many mystics have a background as craftsmen, but the futuwwah associations - ethical urban organisations or 'guilds' in medieval Muslim realms that emphasised honesty, peacefulness, gentleness, generosity, avoidance of complaint, and hospitality in life - brought pietist ideals to the lower classes. Ironically, it was at the time of the Crusades (during the twelfth and thirteenth centuries) that the principal Sufi lineages of the region emerged (among them the Shädhiliyyah, Qãdiryiyyah, Suhrawardiyya, and Mawlaviyyah) along with transnational networks of Sufi lodges funded by rulers and wealthy patrons.

In the three centuries leading up to the Renaissance (c. 1150-1500), Europeans eagerly sought Islamic knowledge. Lost Greek classics that had been preserved in Arabic were re-translated into Latin in Spain and Italy. Ibn Sīnā's (d. 1037; known as Avicenna to the medieval Latin West) 14-volume Canon of Medicine was a primary medical reference used in Europe from the twelfth to the seventeenth centuries. Translations of Muḥammad b. Mūsā al-Khwārizmī’s (d. c. 850) treatise on Indian numerals brought the decimal numbering system to Europe in the twelfth century. His reinvention of algebra enabled Europeans to systematically solve linear and quadratic equations. (Europeans started learning algebra with examples from Islamic inheritance problems!) The European fields of optics, alchemy, chemistry, astrology, physics, and technological processes were correspondingly enriched by pioneering research from the Islamic world. The European Renaissance stood thus on the shoulders of Islamic knowledge. 
In Renaissance Europe, many hated Islam as a religion but admired the culture, knowledge, and artefacts of its civilisation like their medieval counterparts. Later, Goethe (d. 1832), the German poet and playwright, celebrated Persian Islamic culture in his West-östlicher Diwan, a collection of lyrical poems inspired by the Persian poet Hăfiz (d. 1390), and his interest in the Islamic world went beyond mere curiosity. An important outcome of this literature was a further romanticising of Muslims, reinforcing the allure of the Orient with its exotic harem and palace rooms full of mystery, a sensuous culture symbolised by the oriental man surrounded by his concubines. These have been vividly depicted in nineteenth-century European paintings. The image of Islam as a decadent and dying civilisation, backward and sensual, has made its way into popular culture through TV images, Hollywood movies, and reporting by the mass media. We can see here the construction of an 'Other'. ${ }^{6}$

During the twentieth century, boundaries of individual nations became formally established and over time political rule reverted to the people of each Islamic nation-state. By this time, there was a history of almost 1,400 years of mutual antagonism between Christendom and the Middle Eastern Islamic world. At the same time, let us be reminded how the millions of personal interchanges, friendships, and marriages between the illustrious people of these two regions demonstrate the commonality shared among the vast majority of those in the Abrahamic family of religions.

In spite of this, in the latter part of the twentieth century, ongoing animosity to Islam and Muslims escalated into a phobia. One characteristic of this phobia making it Islamophobia is its projection of violence on to Muslims and their religion, which will be discussed in the second part of this article.

\section{From Antagonism to Phobia}

After World War II, the mass media's glowing admiration for the newly formed nation-state of Israel contributed to renewing a relatively dormant Western antagonism toward Islam and Muslims. For the first few decades after 1948, mass media representation typically did not communicate negative images of the "Arab other'. Instead, Israelis were constantly being portrayed as heroes. By implication, in the black and white mass-media world of text and sound bites, the Arabs implicitly became the villains. Because of a relentless media reinforcement of these stereotypes over the years, and more explicit anti-Arab mass media representation beginning in the 1970s, most Westerners now automatically conflate Arabs with Muslims and assume that Muslims are the 'bad guys'?

Positive worldwide mass-media presentation of Israel in the West has been a major factor in Israel's economic survival. If public opinion in the West were to 
turn against the Israelis and sympathise with the Palestinians, for example, the US administration would have a much more difficult time sending billions of dollars in annual subsidies to Israel. One major function of mass media in the modern world is to 'manufacture consent' so that people will acquiesce to government policies. ${ }^{8}$ At the same time, conflicts in the world are headline news and the ongoing IsraeliPalestinian conflict has provided the mass media with a disproportionate number of headlines. Whether unwittingly or by design, the mass media has been involved in subtly reactivating and reinforcing a long-standing antagonism between the West and the Islamic world. The mass media is designed to instil fear by graphically portraying worldwide disasters and potential enemies. At the same time, one cannot blame either the mass media or the formation of the State of Israel for what later became known as 'islamophobia'. Without a long history of Christendom's antagonism toward Islam and Muslims it is unlikely that islamophobia could have developed simply as a result of mass-media coverage. In any case, neither long-standing historical factors nor a mass media bias explains islamophobia. They are factors that provide an environment in which islamophobia can survive and thrive.

A contributing politico-economic factor was the dissolution of the Soviet Union in 1991, since the expanding Communist empire had been a very convenient enemy to justify bloated defence budgets. With the looming fear of a 'Communist menace', the US administration was able to legitimise its increasing control of the population through government surveillance of the citizenry. It also created a demand for huge defence expenditures to support an interventionist foreign policy. US Senator Arthur Vandenberg summarised this principle when he said that for President Truman to get popular support he would have to "scare the hell out of the country". ${ }^{9}$ With a recognised public enemy the government could get public backing for any military action. As Samuel Huntington said to government officials, you have "to create the misimpression that it is the Soviet Union that you are fighting". ${ }^{10}$ Without a Communist enemy it would have been much more difficult to justify such expenditures. The United States does not necessarily need an enemy but it is convenient for generating fear, which in turn supports a foreign policy of military intervention. This facilitates large government allocations of funds for defence spending, which generates defence contracts worth hundreds of billions of dollars of revenue for the military-industrial complex. Enemies are lucrative.

There are cogent arguments and considerable evidence for needing enemies psycho-culturally. ${ }^{11}$ In a study before the $9 / 11$ event, it was concluded that "the psychological dynamics that lead to transference [of the Soviet enemy to another enemy] might involve more interaction with actual conditions in the international environment to spark the phenomenon" (italics in original). ${ }^{12}$ If this is true then it leaves a marvellous opportunity for the media to fill in the 'enemy gap'. Self-aware people, that is people who among other things are aware of their cultural 
programming, do not need enemies, psychologically or otherwise. In this discussion there is a dimension of creating an enemy and islamophobia which involves the cultural 'other' and is used to reinforce one's own cultural identity. The relationship between islamophobia and issues of multiculturalism and identity shall be briefly discussed at the end of the article. Fred Halliday notes (in the context of explaining contemporary hostility to 'Islam') that "there is little evidence, that modern society, 'the West', needs an enemy". Yes and no. Needing an enemy does not explain the hostility to Islam per se. Chomsky's evidence (sources cited in this article) for the power elites in the United States, and the lengths to which these elites will go to maintain power, provide sufficient evidence that if creating an enemy is not necessary, it is quite convenient for their agendas. ${ }^{13}$

A series of events occurred soon after the 'Communist threat' had disappeared. First, the word "Islamophobia" appeared in print in $1991 .{ }^{14}$ Second, in 1993 Samuel Huntington conceptually sought to re-create the 'original cold war', between the West and Islam/Muslims by positing the inevitable civilisational clash between Islam and the West. ${ }^{15}$ The so-called 'original' cold war (guerra fria in Spanish) was between Christian Spaniards and the Muslim invaders and was coined by Don Juan Manuel (d. 1348) to describe what he perceived to be the precarious situation of the Spanish with respect to Muslims in the Mediterranean area. ${ }^{16}$ In 1992, Irving Kristol, the founder of Encounter, proclaims, "Now that the other 'Cold War' is over, the real Cold War has begun." ${ }^{\prime 17}$ Again, the genesis of a term and creation of a new post-Communist enemy do not explain islamophobia, but provide ideal conditions for islamophobia to thrive. The events of 9/11 appeared to be a selffulfilling prophecy of Huntington's assumption of an inevitable conflict between the West and Islam. ${ }^{18}$ Soon after $9 / 11$, islamophobia had become an epidemic. The worldwide obsession with (Muslim) terrorists developed as quickly as the escalation of an unwarranted fear, that is, a phobia, against Muslims.

The mass media, if not a contributing factor to islamophobia, is surely the vector that communicates the phobia. Although technically the mass media is quite diverse, overall there are some common characteristics. By depicting horrific scenes from all over the world, it is an ideal means to instil fear in large populations, especially in countries where the average household watches television eight hours a day. ${ }^{19}$ Michael Sells poignantly sums up the effects of mass media manipulation:

Images of Taliban students sitting above the written text of the Qur'an allegedly 'studying the Qur'an' (when actually they are studying intense political indoctrination), or of Bin Laden surrounded by Arabic script and Islamic symbols, are shown repeatedly by the media, interspliced with pictures of the planes flying into the Towers or other horrors, and with the human suffering of the victims and their relatives and survivors. Once that image-association is made, all the pontifications about how all Muslims are not Taliban 
are as effective as pontifications on the dangers of cigarette smoking after someone has ingested thousands of images of smokers as Marlboro man, Sexy man, Sophisticate Woman, Liberated Woman. Once someone has seen the image association of mass-killer (Saddam, Bin Laden), Islamic symbol (written Qur'an, Muslims praying, sounds of the call to prayer) and atrocity (towers burning and collapsing, relatives of victims in anguish), it becomes extraordinarily difficult, however much one tries, to hear and listen to the voices of the vast world of Islam beyond such fanaticism. ${ }^{20}$

The globalised mass media, financed and controlled by vested interests, contributes directly to islamophobia, capitalising on conflicts in the Islamic world to spread negative images and fear of Muslims. The kind of hate speech directed against Islam and Muslims would never be tolerated if it were focused against any other religious group. The Western mass media effectively legitimise islamophobic attitudes in the name of 'free speech'.

An almost exclusive mass-media focus has been placed on what has come to be labelled as political, militant, and fundamentalist Islam. This is understandable since it is these strands in the Islamic world that are involved in conflict and the mass media thrives on covering conflict. However, it is not a level playing field. Instead of isolating political, economic, and military reasons for actions, the mass media portrays all events involving Muslims as religiously motivated behaviour. Violence perpetrated in the name of religion, in Israel, India, the United States, or Sri Lanka, for example, is rarely if ever associated with adherents of that religion. One hardly ever reads about Hindu, Buddhist, Jewish, and Christian terrorists in the world. ${ }^{21}$ In the context of violence perpetrated in the United States, Steven Salaita, asks in the context of Nidal Hasan's recent (9 November 2009) massacre of 13 US military personnel,

Quickly. What is Dylan Klebold's religion? Eric Rudolph's? Theodore Kaczynski's? Seung-Hui Cho's? Klebold, you may recall, is one of the two Columbine shooters [in Colorado, United States], Rudolph the Atlanta Olympics bomber [in Georgia, United States], Kaczynski the Unabomber [in Montana, United States], and Cho the perpetrator of the Virginia Tech massacre [in Virginia, United States]. You likely don't know what religion each killer practiced (or, in the case of Kaczynski, practices) because even at the height of their media coverage reporters and commentators didn't tell. It never seemed that important. What is Nidal Hasan's religion? This is the sort of question on which high test scores are made. Unlike his peers in the peculiar American community of disgruntled gunmen, Hasan's religion seems monumentally important. It no more explains his atrocious deed than the (unknown) religions of the other shooters explain theirs, but it does inform an extant belief in the United States that Islam is a rigid progenitor of violence. Any violent action undertaken by somebody identified as Muslim, then, becomes the responsibility of the religion and its 1.3 billion [probably closer to 1.57 billion] followers. 
To make matters worse, Islam is perceived as a global threat to Western civilisation and its values. Medieval descriptions of Islam, for example, the 'religion of the sword', the Prophet as a violent person, and Islam as an inherently violent religion, are being recycled into contemporary mass media discourse. Islam is portrayed as a code of belief and action that is irrational, anti-modern, and rigid. This is the so-called 'clash of civilisations' discussed above. One would think that the amount of reliable information written on the Islamic world and the ease of meeting Muslims in the West in the twentieth and twenty-first centuries would have dispelled such ignorance (it has to a certain extent). But it is difficult for a non-specialist to differentiate reliable information about Islam/Muslims from the flood of misinformation that has been published since 2001 in the West. Islamophobia has become a chronic disease, one reinforced by the mass media, religious groups, and other interest groups who benefit, directly or indirectly, from the propagation of fear.

Up to now this article has briefly discussed a few of the many dimensions of islamophobia which include historical, cultural, religious, political, and economic perspectives in addition to the role of the mass media - each a book-length subject. ${ }^{22}$ I have summarised some of these factors to demonstrate how they work together to create a favourable environment for the disease of islamophobia to spread. Over the past 20 years, I have noted that the main preconceptions of Western university students about Islam are of violent bearded Muslim men and headscarfed oppressed Muslim women. ${ }^{23}$ The next two sections are a preliminary inquiry into the first of these associations: Islam and violence.

\section{Islam: The Religion of the Sword?}

To reiterate, the notion of Islam as the 'religion of the sword' appears to be deeply embedded both in Christendom's and the modern West's collective cultural unconscious. One might suspect that this is due to concrete historical events, for example, in 1453 when Turkish Muslims conquered Constantinople, the centre of Eastern Christendom for over a millennium. From 1529 onward, the 'sword of Islam' turned westward toward Europe as the Ottomans articulated explicit military designs to conquer Europe until the failed Siege of Vienna in 1683. For several centuries, Muslims were a real threat to Christendom and an actual military enemy for 154 years. From a European perspective, Islam was 'the religion of the sword'. ${ }^{24}$ These historical events, however, cannot explain the twenty-first century Western fixation of labelling Islam as the 'religion of the sword'. Otherwise, one would expect many other religions to be associated with the sword because all politically influential religions have resorted to violence. Yet Muslims and Jews do not label Christianity as the 'religion of the sword' any more than those conquered by the 
Tibetans during their period of empire (c. 610-840) labelled Tibetan Buddhism as the 'religion of the sword'. There is thus much more going on.

There are data to strongly suggest that Christendom projected its own 'use of the sword' upon the established Muslim 'Other'. Western Christendom stridently labels Islam as the 'religion of the sword' at the time of the Crusades in the Middle East (1095-1291). Sigebert of Gembloux (d. 1112), for instance, starkly contrasts Islam and Christianity. Islam is the religion of the sword while Christianity is the religion of love. ${ }^{25} \mathrm{He}$ is followed by the influential Peter the Venerable (d. 1156) who also describes Islam as the religion of the sword. Finally, Vincent de Beauvais (d. 1264), the writer of the definitive medieval European encyclopaedia Speculum

Maius, depicts Muhammad as someone who "converted people to his faith "with the sword, force and destruction' [...] and Islam as a religion of the sword and vice" ${ }^{26}$ These accounts are a sample of Christendom's projections of violence as the Christians themselves are taking up the sword against Muslims. ${ }^{27}$ This is only the beginning of Christendom projecting its violent dark side on its chosen external 'Other'. Christendom's involvement in violence demonstrates how powerful the psycho-cultural mechanism of projection can be. In the next section I seek to explain deeper psychological factors involved in islamophobia.

\section{Violence and the 'Dark Side of the West'}

It is tempting to think that the modern disease of islamophobia, a fear of Islam and Muslims with no rational basis, is the culmination of centuries of Western European antagonism toward Muslims/Islam. However, it is quite problematic to extrapolate or posit a cause and effect relationship between medieval Christendom's attitudes toward Islam and modern islamophobic discourse and behaviour, even if the language and imagery have remarkable similarities. The question still remains: why is one primary marker for creating the 'Muslim Other' focused on violence? I would argue that Christendom/the West has been projecting its own violent 'dark side' onto Islam/the Muslims.

This principle of projection in individuals was one of Sigmund Freud's contributions to modern psychology. He postulated that individuals project their own unacknowledged negative character traits on others. The aggregate of these negative traits has been called the 'dark side' because these traits are invisible to the individual. This is how an '(evil) other' is created psychologically. The same principle of projection applies to groups, whether they are tribes, religions, or nations. That is, they project their 'dark side' on other groups, effectively creating an 'other' or an 'enemy'. There is an objectification of evil when an individual unconsciously transfers what he considers negative (and is a part of the individual he chooses not to acknowledge) onto another person or group. "We use them [the 
other or enemy] for the externalisation of our bad self- and object images; these we may superimpose upon (or condense with) the projections of our unacceptable thoughts. ${ }^{28}$ A Cypriot Turkish psychologist discusses his experience:

In Cyprus, a Greek child learns from what his mother says and does that the neighborhood church is a good place; he unconsciously invests in it for safekeeping his unintegrated good aspects, and feels comfortable being in or near this building. The same mechanism makes him shun the Turkish mosque and minaret, into which he deposits the unintegrated bad aspects of himself $[\ldots] .{ }^{29}$

Let's investigate very briefly Christendom's involvement in religiously motivated war (which is never only just religious). The Crusades against the Muslims in the Middle East were only one of the many crusades organised by the Popes of the Western Christian church. In the Fourth Crusade (1202-04), Venetian and other Western soldiers attacked fellow Christians and sacked Constantinople. There was the Albigensian Crusade (1209-1229) for 20 years against the Cathars in southern France, as well as the Crusades in the Baltic regions. Estimates of the deaths involved in these last two crusades spiral into the hundreds of thousands. ${ }^{30}$ Then there was the Spanish Inquisition (1478-1834), originally set up to convert Spanish Jews and Muslims to Christianity, with an estimated 250,000 deaths involved. ${ }^{31}$ In the Christian conquest of the Americas millions of native peoples perished. In passing, one should note how the spread of Islamic rule in the seventh and eighth centuries is called the 'Islamic Conquests', but in the West we never hear about the corresponding 'Christian Conquests' of Eastern Europe, America, Australia, or New Zealand. Even with the lowest population estimate of 10 million inhabitants in the Americas, there were roughly half that number in less than a hundred years after the conquests (1600) and half of that remaining number was exterminated in the ensuing three centuries. ${ }^{32}$ According to James B. Wood, the French Wars of Religion (1562-98) had 1,259,220 deaths in just the first 20 years. ${ }^{33}$ The bloodiest European war before the nineteenth century was the Thirty Years' War (1618-48) between Protestants and Catholics, which had over 2 million deaths and where an estimated 15 per cent to 20 per cent, if not more, of the population of Germany died. ${ }^{34}$

When we look at the history of pre-nineteenth-century Christendom, we find a very high level of wholesale violence expressed through conquest and deaths from religiously motivated wars. ${ }^{35} \mathrm{It}$ is true that Christendom was not unique in violence or religiously motivated violence. However, the crucial point is the incongruence between a high level of violence, a self image of Christianity being the 'religion of love', and then the move to define Islam as the 'religion of the sword'. This demonstrates clear denial and projection.

The psycho-cultural factor of projection, or using another group as a 'target of externalisation', is one way of highlighting culturally shared interpretations, ${ }^{36}$ 
which in this study are antagonistic attitudes toward Islam/Muslims. Like Volkan, this article asserts that investigating the process of creating targets of externalisation is useful in explaining the persistence of violence. ${ }^{37}$ Islamophobia is a form of violence, especially when one group's own denied violence is projected on to the Muslim Other..$^{38}$ I have explained how Christendom's antagonism towards Islam/ Muslims developed into one predominant (among others) historically shared social interpretation of Islam. This projected antipathy toward Islam is the cultural legacy in which islamophobia has developed in the West. Unfortunately an association of Islam/Muslims with violence is not only found in the West, but has spread like a virus to other parts of the world via the mass media.

This process of 'essentialising the Other' and transferring negative traits is not a monopoly of the West. The governments of many majority-Muslim countries continue to portray the West as 'immoral' and 'decadent', highlighting morally shocking news events in government-controlled media. Egyptian media in the early 1980s, for instance, reinforced this image by televising an American soap opera, Dallas, which portrayed behaviour that most Americans themselves would also consider morally reprehensible. Labelling the United States as the 'Big Satan' (in Persian; kishwar-i shaytān-i buzurg) by Iranian revolutionaries is another well-known example. Many governments of Muslim countries continue to blame their own homemade present problems on events that happened generations ago rather than taking responsibility for these social and economic problems. Most of this is psychological transference on to former European colonial powers, but in the Arab world this can even involve blaming the Ottoman Turks for present-day problems.

\section{Conclusion and Recommendations}

Using Islam and the Muslims as the West's target of externalisation says much about deep-seated cultural fears in the West. This writer has approached islamophobia as a 'disease', if not a 'virulent disease', that has been fostered by many political, economic, cultural, and religious factors. It is a psychological manifestation of the West's long history of denying its own violence projected upon Islam and Muslims.

There are those, like Fred Halliday, who prefer not to acknowledge that such a pathological phobia like islamophobia has deep cultural roots in Christendom/the West, and prefer an interpretation that "offers more hope" so that then "it is more likely that something can be done". ${ }^{39}$ His intent, as I read it, is that one should not essentialise cultural characteristics or people. In this I am in total agreement, since essentialising is a dehumanising concomitant symptom of islamophobia which prevents any possibility of change. 
- If the West were inherently anti-Islamic and Islam/Muslims were inherently violent then a never-ending conflict would be inevitable. This is one of the false assumptions of Huntington's so-called 'clash of civilisations'. People and cultures have changed, are changing, and will continue to change. Indeed, change is one characteristic that does not change.

- I differ with Halliday, however, on one crucial point. When dealing with a serious disease, not to recognise the chronic condition is to forever be dealing with symptoms. When one suppresses (read denies) symptoms, the chronic condition is only exacerbated. This chronic condition is the denial of violence and the resulting pathological phobia against Islam/Muslims. I personally wish this were not the case, but that is how the disease profile looks.

- We humans have a monumental healing task ahead of us and are seriously challenged to exercise the requisite spiritual skills for this healing process to occur in a timely manner. As many aspects of modern life have become globalised, there is also a simultaneous interconnectedness of religio-cultural ideas, wisdom, and prejudices.

Up to this point, the interconnectedness of the prejudices and the ignorance thereof has overshadowed that of wisdom. Islamophobia is a prime example. Wisdom affirms and nurtures our common human reality of being one family. Increasingly closer contact between differing cultures, ideas, and ways of living is not being matched by increased awareness of who we are. This creates conditions such that misunderstandings and prejudices surface much more easily, are denied, and in turn projected on to growing minorities.

- There is thus a need to balance a heart-felt acknowledgement of our common humanity with the acknowledgement of the factors preventing this greater awareness, e.g., our 'dark side'.

Global warming and environmental degradation are well publicised, but what about the increasing fear of 'the Other' around the world? If we cannot live with each other as we come increasingly in closer contact, then the resultant social strain will be at least as dangerous as these other global problems.

The United States, an immigrant society, is having difficulties with the scale of population shifts, primarily involving the mushrooming population of Hispanics and the increasingly public use of Spanish. ${ }^{40}$ In Europe it is the Muslim communities that are the focus of paranoia. Despite millions of immigrants, the nations of Europe are not immigrant countries and they do not have a historical record of multiculturalism. ${ }^{41}$ The increasing multicultural reality in large cities of the world, along with large movements of people as refugees and immigrants, is another factor to consider. 
This is all potential fuel for increasing islamophobia. Combine this with economic uncertainty and the use of fear by governments to control their populations, and it is a formula for targeting minorities and immigrant communities. Denial, projection, and the lack of self-awareness are psycho-spiritual luxuries that we can no longer afford. We human beings either chart a common destiny or there will be no earthly destiny for anyone.

In closing, there is thus no room for mutual distrust - that is to say, for undifferentiated hatred for the West/Westerners from the part of Muslims on the one hand and 'islamophobia' from the part of the West/Westerners on the other.

\section{Notes}

1. Here I would like to acknowledge the shared history and culture between Christendom and the Islamic world and recommend Anouar Majid, We Are All Moors: Ending Centuries of Crusades against Muslims and Other Minorities (Minneapolis MN: University of Minnesota Press, 2009), whose insights I have not incorporated in this article. By 'the West' I mean the regions of Europe, North America, and Australasia after the eighteenth century, which are still generally Christianbased cultures in spite of the rainbow of other religio-cultural groups living there. Prior to the nineteenth century, I refer to (European) Christendom. Islam is the name of a religion but it is not an entity that can do anything. Technically, it is a verbal noun (islām, lit. 'surrendering' [to God]) and Muslims are the actors. At times, I have tried to remind the reader of this when writing Islam/ Muslims throughout the article. There is also considerable hostility toward Islam/Muslims and islamophobia in India and Russia but the etiology/genealogy of the 'disease' differs from that of the 'West'.

2. Ernest Lavisse's Histoire de France, used as a textbook until the 1950s, depicted the Battle of Poitiers as the pivotal battle that saved the unborn nation of France from the forces of darkness. Hans Delbrück declared that "There was no more important battle in the history of the world" in his Carnage and Culture: Landmark Battles in the Rise to Western Power. American military historian Victor Davis Hanson expressed the same opinion. See also David Levering Lewis's comments in a summary of a conference at New York University, entitled "Europe and Islam: Shared History, Shared Identity", available online at http://islamuswest.org/events_Islam_and_the_West/ europe_islam_shared_identity/europe_and_islam_history_report_01.html (accessed on 8 February 2011).

3. David Levering Lewis, God's Crucible: Islam and the Making of Europe, 570 to 1215 (New York: W.W. Norton, 2008), 172-3. He also refers to this event in his comments cited above.

4. See the essays in Emmanouela Grypeou et al,, eds, The Encounter of Eastern Christianity with Early Islam (Leiden: Brill, 2006).

5. See Matti Moosa, The Crusades: Conflict Between Christendom and Islam (Piscataway NJ: Gorgias Press, 2008) and John Meyendorff, The Byzantine Legacy in the Orthodox Church (Yonkers NY: St Vladimirs Seminary Press, 2000), 101.

6. See Ibrahim Kalin, "Roots of Misconception: Euro-American Perceptions of Islam Before and After September 11th", in: Joseph Lumbard (ed.), Islam, Fundamentalism, and the Betrayal of Tradition (Bloomington IN: World Wisdom, 2004), 143-87.

7. See Kai Hafez (ed.), Islam and the West in the Mass Media: Fragmented Images in a Globalising World (Cresskill NJ: Hampton Press, 1999) and Edward Said, Covering Islam: How the Media and the Experts Determine How We See the Rest of the World (New York: Vintage, 1997).

8. See Edward Herman and Noam Chomsky, Manufacturing Consent: The Political Economy of the Mass Media (New York: Pantheon, 2002). 
9. John Trumprour, "The Clash of Civilisations", in: Emran Qureshi and Michael Sells, The New Crusades: Creating the Muslim Enemy (New York: Columbia University Press, 1993), 91.

10. Samuel Huntington et al., "Vietnam Reapraised" [A roundtable discussion], International Security (Summer 1984), 14.

11. See Vamik Volkan, "The Need to Have Enemies and Allies: A Developmental Approach", Political Psychology 6, no. 2 (1984), 217-42. "It can be said that there would be no political psychology if individuals and groups did not have a need for enemies among other groups [...]" (ibid.: 221).

12. See Shoon Kathleen Murray and Jason Meyers, "Do People Need Foreign Enemies? American Leaders' Beliefs after the Soviet Demise", Journal of Conflict Resolution 43, no. 5 (October 1999), 567.

13. See Fred Halliday, “'Islamophobia' Reconsidered”, Ethnic and Racial Studies 22, no. 5 (1999), 895.

14. The first mention of Islamophobia is in Insight 4 (February 1991), 37, according to the 1997 edition of the Oxford English Dictionary. 'Islamophobia' was defined in the 1997 Runnymede Trust report as "unfounded hostility towards Islam, and therefore fear or dislike of all or most Muslims". See Islamophobia, a Challenge for Us All: Report of the Runnymede Trust Commission on British Muslims and Islamophobia (London: Runnymede Trust, 1997), 1. There are seven characteristics of a closed view of Islam outlined in this report, the first six all contributing to and culminating in a "phobic dread of Islam" (ibid.: 5).

15. Samuel Huntington, "The Clash of Civilisations?", Foreign Affairs 72, no. 3 (1993), 22-49. Also note Margaret Thatcher's comment, "Islamism is the New Bolshevism", in: Robin Richardson (ed.), Islamophobia: Issues, Challenges, and Action: A Report by the Commission on British Muslims and Islamophobia (Stoke on Trent [UK]: Trentham Books, 2004), 17.

16. Fred Halliday, The Making of the Second Cold War (London: Verso, 1986), 5.

17. Irving Kristol, "My Cold War", The National Interest (Spring 1993), 143-4; from a 1992 conference; cited in Trumprour, "The Clash", 107-8.

18. For an exposé of Huntington's embarrassing ignorance of the Islamic world see Roy Mottahedeh, "The Clash of Civilisations: An Islamicist's Critique", in: Qureshi and Sells, The New Crusades, $131-51$.

19. The Economist, 23 September 2009.

20. See http://groups.colgate.edu/aarislam/msells.htm (accessed on 8 February 2011).

21. This small-scale non-governmental terrorism is what Chomsky has aptly termed "retail terrorism". Governments, particularly after the Vietnam War, do not tolerate media coverage of "wholesale terrorism", which is why most journalists in Afghanistan and Iraq are "embedded" journalists. For the nuances of these types of terrorism see Noam Chomsky and Carlos Otero, Language and Politics (Oakland CA: AK Press, 2004), 543.

22. For a selection of perspectives, in addition to the books already cited, see Elizabeth Poole, Reporting Islam: Media Representations of British Muslims (London: I.B. Tauris, 2002) and Tareq Ismael and Andrew Rippin, Islam in the Eyes of the West: Images and Realities in an Age of Terror (New York: Routledge, 2009); Elzain Elgamri, Islam in the British Broadsheets: The Impact of Orientalism on Representations of Islam in the British Press (Reading [UK]: Ithaca Press, 2008). There are also those who do not deny that islamophobia exists, but who reduce it to racism; see Faisal Bodi, "Islamophobia Should be as Unacceptable as Racism", The Guardian (London), 12 January 2004, available online at http://www.guardian.co.uk/politics/2004/jan/12/race.religion (accessed on 30 January 2011). Others deny the concept altogether; see Paul Belien and Filip van Laenaen, "Muslims Create Islamophobes, Then Want Islamophobes Punished", The Brussels Journal, 14 February 2006, available online at http://www.brusselsjournal.com/node/816 (accessed on 30 January 2011). These latter references were suggested by the anonymous reviewer.

23. The fastest way to deal with the former is to supply students with simple statistics on terrorism. From 1980 to 2005, only 6 per cent of terrorist attacks in the United States involved Muslims (who are roughly 6 per cent of the US population) and in the only terrorist reports available from EUROPOL (2006-08) only 0.4 per cent involved Muslims; see http://www.loonwatch.com/2010/01/ 
terrorism-in-europe/ (accessed on 30 January 2011). As for the latter, I invite Muslim women from the local community to discuss their lives and have an open conversation with the students. There are no quick fixes here since these islamophobic stereotypes are deeper than simple mental constructs. The major root of the problem is students' unawareness of media conditioning, which is where these attitudes often originate. Half of the final exam is for them to collect 14 newspaper articles on Islam and analyse them. In that manner, they have an opportunity to see the conditioning process for themselves.

24. The conquest of Spain could be mentioned here but my reading of the historical sources does not indicate an intentional programme to conquer all of Europe.

25. Svetlana Luchitskaja, "The Image of Muhammad in Latin Chronography of the Twelfth and Thirteenth Centuries", Journal of Medieval Studies 26, no. 2 (2000), 120.

26. Ibid., 125.

27. See R.W. Southern, Western Views of Islam in the Middle Ages (Cambridge MA: Harvard University Press, 1962). Byzantine sources labelling Islam as the 'religion of the sword' may exist, but I have not been able to find any Byzantine sources in the secondary literature to describe Islam in this manner. What is important is that these three writers are from Western Europe.

28. Volkan, "The Need to Have Enemies", 244.

29. Ibid., 235.

30. R.J. Rummel, "Table 2.1a Pre-20th Century Democide Estimates, Sources, and Calculations", available online at http://www.hawaii.edu/powerkills/SOD.TAB2.1A.GIF (accessed on 8 February 2011).

31. Ibid.

32. Massimo Livi-Bacci, "The Depopulation of Hispanic America after the Conquest", Population and Development Review 32, no. 2 (June 2006), 199-232.

33. James B. Wood, "The Impact of the Wars of Religion: A View of France in 1581", Sixteenth Century Journal 15 , no. 2 (Summer, 1984), 131-68. The number in the text here is calculated by multiplying the average of casualties above normal death rates per diocese per year for the first 20 years (677) times the number of dioceses (93) times the number of years (20). I find it very interesting how the aggregate deaths, which I had to personally calculate, are not mentioned in the article.

34. "It is consequently by no means extravagant to posit population 'losses' of 90 percent in some areas, particularly on the regular military routes used by so many ravaging armies. Incomplete registers of births and deaths, and irregularity of high mortality caused by epidemics, make it virtually impossible to arrive at a death rate attributable to the war. Estimates can be made for casualties in battles and sieges, but these are invariably dwarfed by the deaths attributed to 'plague'." See Henry Kamen, "The Economic and Social Consequences of the Thirty Years' War", Past \& Present 39 (April 1968), 49.

35. Looking at Rummel's pre-twentieth-century tables (which he acknowledges to have very incomplete data), it is clear that large-scale democide occurred throughout human history and no religious/ ethnic group had a monopoly. The Mongols, not surprisingly, are very high on the list of pre-modern democide perpetrators with over 40 million people being killed by them (and an additional 17 million during Tamerlane's rule). See also R.J. Rummel, Death by Government (New Brunswick NJ: Transaction Publishers, 1997) for his studies of twentieth-century democide.

36. Volkan, "The Need", 231.

37. Marc Howard Ross, "Social Structure, Psychocultural Dispositons, and Violent Conflict: Extensions from a Cross-Cultural Study", in: James Silverberg and Patrick Gray (eds), Aggression and Peacefulness in Humans and Other Primates (Oxford: Oxford University Press, 1992), 286.

38. Is it coincidence that in 2008 the United States and the European Union spent 65 per cent of the 1.2 trillion US dollars (the world total for military expenditures) with only 17 per cent of the world's population? Between Russia and the United States there are enough nuclear weapons to destroy the world many times over; see the statistics from the Stockholm International Peace Research Institute, available online at http://www.sipri.org/yearbook/2008/05 (accessed on 8 February 2011). This is gearing up for wholesale terrorism run amok. 
39. Halliday, “'Islamophobia' Reconsidered”, 895.

40. For difficulties experienced by American Muslims in the aftermath of 9/11 see Osman Bakar, "Post-9/11 Islamophobia and the Future of American Islam", in: Southeast Asia Regional Centre for Counter-Terrorism (SEARCCT) (ed.), SEARCCT's Selection of Articles (Kuala Lumpur: SEARCCT and Malaysian Ministry of Foreign Affairs), 57-69.

41. For issues of multiculturalism and islamophobia see Gabriele Marranci, "Multiculturalism, Islam and the Clash of Civilisations Theory: Rethinking Islamophobia", Culture and Religion 5, no. 1 (2004), 105-16. It is a good example of why history should be considered in a scholarly analysis of contemporary events. 